\title{
PENERAPAN DATA MINING UNTUK PEMESANAN PEMESANAN PERCETAKAN BAHAN AJAR DENGAN ALGORITMA APRIORI (STUDI KASUS : PERCETAKAN WENDY)
}

\author{
Nurmawaty Hutabarat ${ }^{1}$, Jijon Raphita Sagala ${ }^{2}$, Asaziduhu Gea ${ }^{3}$ \\ ${ }^{1,2}$ Teknik Informatika, STMIK Pelita Nusantara, Jl. Iskandar Muda No. 1, Medan, 20154, Indonesia \\ ${ }^{3}$ Teknik Informatika, Universitas Methodist Indonesia, Jl. Hang Tuah No. 8, Medan, 20152, Indonesia \\ nurmawaty95hutabarat@gmail.com ${ }^{1}$, sisagala@gmail.com ${ }^{2}$, gea.asaziduhu@gmail.com ${ }^{3}$
}

\section{ABSTRACT}

\begin{abstract}
Wendy's printing is one of the printing presses in collaboration with the University of Santo Thomas, especially in the field of computer science, the printing of Wendy is located on the faithful road of UNIKA campus intersection. Print leaders and employees sometimes have difficulty finding out how much teaching material has been printed in one transaction, so that the leader of Wendy's printing press is still manual / speculating in teaching material.The application of data mining for ordering the teaching of teaching materials at the computer science faculty of the university of Saint Thomas is designed to produce this rule can produce rules / rules of association can be seen and analyzed the results, so that the printing leader can see a frequency of teaching materials that often occur in each transaction.Therefore, analysis and testing is carried out, it is hoped that it can provide information about the transaction patterns of teaching materials that often appear. So that it can help the owner in making decisions to order and print teaching materials.
\end{abstract}

Keywords: Data Mining, Wendy Printing, Apriori Algorithm, Association.

\section{Pendahuluan}

Percetakan Wendy bergerak di bidang percetakan buku dan penjualan ATK (Alat Tulis Kantor), yang hampir setiap harinya mencetak bahan ajar untuk mahasiswi Universitas Katolik Shanto Thomas Sumatera Utara (UNIKA SU) yang mana sistem pemesanannya masih manual dan tentu Pola pembelian konsumen di tiap harinya berbeda-beda hal ini perlu dianalisis lebih jauh sehingga dapat menghasilkan informasi yang bermanfaat yang dapat digunakan dalam pengambilan keputusan dan dapat menunjang proses bisnis pada toko tersebut serta memaksimalkan keuntungan yang bisa diperoleh.

Data mining merupakan suatu proses penggalian data atau penyaringan data dengan memanfaatkan kumpulan data dengan ukuran yang cukup besar melalui serangkaian proses untuk mendapatkan informasi yang berharga dari data tersebut. Data mining bisa digunakan oleh perusahaan besar untuk menggali data untuk mendapatkan informasi yang dapat menunjang dan meningkatkan proses bisnis perusahaan tersebut.

Apriori merupakan algoritma yang banyak digunakan untuk menentukan pola hubungan antar produk yang sering dibeli dalam suatu toko atau swalayan. Algoritma ini akan memberikan saran kepada manajer untuk melakukan strategi promosi pada swalayan atau toko yang dimilikinya. Pemetaan assocition rule yang dihasilkan algoritma ini digunakan untuk mengatur meletakkan barang-barangnya dalam tempat yang strategis agar pembeli lebih mudah menjumpainya

\section{Landasan Teori}

\subsection{Data Mining}

Eko Prasetyo mendefinisikan data mining sebagai proses untuk mendapatkan informasi yang berguna dari gudang basis data yang besar.

Muchlisin Riadi mendefenisikan Data mining adalah proses menemukan sesuatu yang bermakna dari suatu korelasi baru, pola dan tren yang ada dengan cara memilah-milah data berukuran besar yang disimpan dalam repositori, menggunakan teknologi pengenalan pola serta teknik matematika dan statistik.Istilah data mining kadang disebut juga Knowledge discovery.

\subsection{Association Rule}

Berikut Langkah-langkah proses perhitungan association rules.

1) Sistem men-scan database untuk mendapat kandidat 1-itemset (himpunan item yang terdiri dari 1 item) dan menghitung nilai supportnya. Kemudian nilai supportnya tersebut dibandingkan dengan minimum support yang telah ditentukan, jika nilainya lebih besar atau sama dengan minimum support maka itemset tersebut termasuk dalam large itemset.

2) Itemset yang tidak termasuk dalam large itemset tidak diikutkan dalam iterasi selanjutnya di pangkas (di prune).

3) Pada iterasi kedua sistem akan menggunakan hasil large itemset pada iterasi pertama (L1) untuk membentuk kandidat itemset kedua (L2). Pada iterasi selanjutnya sistem akan menggunakan hasil large itemset pada iterasi 
selanjutnya akan menggunakan hasil large itemset pada iterasi sebelumnya (Lk-1) untuk membentuk kandidat itemset berikut (Lk). Sistem akan menggabungkan (join) Lk-1 dengan Lk-1 untuk mendapatkan Lk, seperti pada iterasi sebelumnya sistem akan menghapus/pemangkasan (prune) kombinasi itemset yang tidak termasuk dalam large itemset.

4) Setelah dilakukan operasi join, maka pasangan itemset baru hasil proses join tersebut dihitung supportnya.

5) Proses pembentuk kandidat yang terdiri dari proses join dan prune akan terus dilakukan hingga himpunan kandidat itemsetnya null, atau sudah tidak ada lagi kandidat yang akan dibentuk.

6) Setelah itu, dari hasil frequent itemset tersebut dibentuk association rule yang memenuhi nilai support dan confidence yang telah ditentukan.

7) Pada pembentukan association rule, nilai yang sama dianggap sebagai satu nilai.

8) Assosiotion rule yang terbentuk harus memenuhi nilai minimum yang telah ditentukan.

Minimal Support : sebuah nilai yang ditentukan sendiri oleh peneliti untuk memangkas kombinasi item set menjadi lebih sedikit.

Minimal Confidence sebuah nilai yang ditentukan juga oleh peneliti untuk memangkas kombinasi setiap k-item set (hasil dari pemangkasan minimal support) untuk membentuk aturan asosiasi.

Metodologi dasar analisis asosiasi terbagi menjadi dua tahap:

1) Support

Support dari suatu association rule adalah presentasi kombinasi item tersebut dalam database, dimana jika mempunyai item A dan item B maka support adalah proporsi dari transaksi dalam database yang mengandung A dan B.

Nilai support sebuah item diperoleh dengan rumus.

$$
\begin{gathered}
\text { Support }(A)= \\
\frac{\text { Jumlah transaksi mengandung } A}{\text { Total Transaksi }}
\end{gathered}
$$

Sedangkan nilai support dari 2 item diperoleh dari rumus berikut:

$\operatorname{Support}(A, B)$

$$
\operatorname{Support}(A, B)=P(A \cap B)
$$

$$
=\frac{\sum \text { Transaksi mengandung } A \text { dan } B}{\sum \text { Transaksi }}
$$

2) Confidence

Confidence dari association rule adalah ukuran ketepatan suatu rule, yaitu presentasi transaksi dalam database yang mengandung A dan mengandung $\mathrm{B}$.
Confidence $=P(B \mid A)$
$=\frac{\sum \text { Transaksi mengandung } A \text { dan } B}{\sum \text { Transaksi mengandung } A}$

\subsection{Algoritma Apriori}

Algoritma Apriori adalah salah satu algoritma yang melakukan pencarian frequent itemset dengan menggunakan teknik association rule (irfan, 2013) Algoritma Apriori menggunakan pengetahuan frekuensi atribut yang telah diketahui sebelumnya untuk memproses informasi selanjutnya. Pada algoritma Apriori menentukan kandidat yang mungkin muncul dengan cara memperhatikan minimum support dan minimum confidence. Support adalah nilai pengunjung atau persentase kombinasi sebuah item dalam database. adalah:

secara garis besar cara kerja algoritma apriori

1) Pembentukan kandidat itemset, Kandidat kitemset dibentuk dari kombinasi (k-1)-itemset yang didapat dari iterasi sebelumnya. Satu ciri dari algoritma Apriori adalah adanya pemangkasan kandidat k-itemset yang subsetnya yang berisi $\mathrm{k}-1$ item tidak termasuk dalam pola frekuensi tinggi dengan panjang k-1.

2) Penghitungan support dari tiap kandidat kitemset. Support dari tiap kandidat k-itemset didapat dengan men-scan database untuk menghitung jumlah transaksi yang memuat semua item di dalam kandidat k-itemset tsb. Ini adalah juga ciri dari algoritme Apriori dimana diperlukan penghitungan dengan scan seluruh database sebanyak k-itemset terpanjang.

3) Tetapkan pola frekuensi tinggi. Pola frekuensi tinggi yang memuat $\mathrm{k}$ item atau $\mathrm{k}$ itemset ditetapkan dari kandidat k-itemset yang support-nya lebih besar dari minimum support.

4) Bila tidak didapat pola frekuensi tinggi baru maka seluruh proses dihentikan. Bila tidak, maka k ditambah satu dan kembali ke bagian ke 1.

\section{Analisa Dan Perancangan \\ 3.1 Analis Algoritma Apriori}

Data yang diambil merupakan data transaksi penjualan pada tahun 2017. Data tersebut adalah data yang mewakili keseluruhan data transaksi sebanyak 50 transaksi.

TABEL 1

TABEL DATA TRANSAKSI PENJUALAN BUKU

\begin{tabular}{cll} 
No & \multicolumn{3}{c}{ Item Yang Dibeli } \\
\hline 1 & Pengantar Ilmu Komputer, Algoritma dan \\
& Pemograman, Struktur Data, Basis Data,
\end{tabular}


Kecerdasan Buatan, Metode Penelitian, Pengolahan Citra, Bahasa Rakitan

2 Algoritma dan Pemograman, Struktur Data, Kecerdasan Buatan, Sistem Pakar, Bahasa Rakitan , Etika Profesi, Pengolahan Citra, Data Mining, Keamanan Komputer, Logika Fuzzy

3 Kecerdasan Buatan, Sistem Pakar, Data Mining, Pengolahan Citra, Etika Profesi, Logika Fuzzy, Web Programming, Struktur Data

4 Web Programming, Bahasa Pemograman $\mathrm{C}++$, Etika Profesi, Logika Fuzzy, Kecerdasan Buatan, Struktur Data, Sistem Pakar, Data Mining

5 Teknik Riset Operasi, Administrasi Jaringan, Pemograman Client/Server, Web Programming

6 Data Mining, Pengantar Ilmu Komputer, Sistem Pakar, Struktur Data, Etika Profesi, Pengolahan Citra, Keamanan Komputer, Bahasa Rakitan, Kecerdasan Buatan

7 Pemodelan Simulasi, Kewirausahaan, Logika Fuzzy, Data Mining, Bahasa Rakitan, Administrasi Jaringan, Kecerdasan Buatan, Keamanan Komputer

8 Keamanan Komputer, Bahasa Rakitan, Metode Penelitian, Sistem Informasi

9 Manajemen Proyek, Pengolahan Citra, Etika Profesi, Perangkat Lunak Aplikasi, Pemograman Mobile, Pemodelan Simulasi, Struktur Data, Kecerdasan Buatan, Sistem Pakar, Bahasa Rakitan, Data Mining, Keamanan Komputer, Logika Fuzzy

10 Data Mining, Logika Fuzzy, Bahasa Rakitan, Kecerdasan Buatan, Pengolahan Citra, Keamanan Komputer, Etika Profesi, Struktur Data, Sistem Pakar

11 Sistem Informasi, Perangkat Lunak Aplikasi, Rekayasa Perangkat Lunak, Administrasi Jaringan, Bahasa Pemograman $\mathrm{C}++$, Pemograman Client/Server, Data Mining, Logika Fuzzy

12 Pengantar Ilmu Komputer, Struktur Data, Kecerdasan Buatan, Metode Penelitian, Logika Fuzzy, Sistem Pakar, Pemodelan Simulasi, Etika Profesi

13 Pengantar Arsitektur Komputer, Teori Bahasa dan Automata, Administrasi Jaringan, Etika Profesi, Sistem Informasi, Logika Fuzzy, Sistem Pakar, Kecerdasan Buatan, Struktur Data, Data Mining

14 Struktur Data, Pemograman Mobile, Pengolahan Citra, Pengantar Arsitektur Komputer, Data Mining, Etika Profesi, Bahasa Rakitan, Logika Fuzzy, Keamanan Komputer

15 Logika Fuzzy, Data Mining, Kewirausahaan, Bahasa Rakitan, Teori Bahasa dan Automata, Keamanan Komputer

16 Bahasa Rakitan, Sistem Pakar, Pengolahan Citra, Keamanan Komputer, Bahasa Pemograman $\mathrm{C}++$, Algoritma dan Pemograman

17 Logika Informatika, Jaringan Komputer, Kecerdasan Buatan, Etika Profesi, Keamanan Komputer, Logika Fuzzy, Sistem Pakar, Struktur Data, Data Mining

18 Kewirausahaan, Teori Bahasa dan Automata, Kecerdasan Buatan, Teknik Riset Operasi, Pemograman Mobile, Etika Profesi

19 Sistem Pakar, Keamanan Komputer, Pengantar Ilmu Komputer, Jaringan Komputer, Bahasa Rakitan, Basis Data, Pengolahan Citra
20 Administrasi Jaringan, Keamanan Komputer, Bahasa Rakitan, Manajemen Proyek, Web

21 Programming Pemodelan Simulasi, Sistem Informasi, Perangkat

22 LunakAplikasi, Pemograman Client/Server, Logika Fuzzy

23 Bahasa Pemograman $\mathrm{C}++$, Jaringan Komputer, Teknik Riset Operasi, Kewirausahaan, Logika

24 Informatika

Teknik Simulasi dan Proyek, Metode Penelitian, Pengantar Arsitektur Komputer, Basis Data

25 Data Mining, Bahasa Rakitan, Kecerdasan Buatan, Manajemen Proyek, Logika Fuzzy, Keamanan

26 Komputer

Web Programming, Bahasa Rakitan, Teknik Riset Operasi, Administrasi Jaringan, Pengolahan Citra,

27 Metode Penelitian, Keamanan Komputer Sistem Informasi, Kewirausahaan, Bahasa Rakitan

28 , Bahasa Pemograman C++, Sistem Pakar, Kecerdasan Buatan, Pengolahan Citra, Keamanan Komputer

29 Jaringan Komputer, Pengantar Ilmu Komputer, Etika Profesi, Data Mining, Pemograman Mobile,

30 Sistem Pakar, Logika Fuzzy

Bahasa Pemograman C++, Keamanan Komputer,

31 Pemodelan Simulasi, Bahasa Rakitan, Teori Bahasa dan Automata

32 Sistem Informasi, Teori Bahasa dan Automata, Logika Informatika, Kecerdasan Buatan

Perangkat Lunak Aplikasi, Rekayasa Perangkat

33 Lunak, Teknik Riset Operasi, Administrasi Jaringan

34 Bahasa Rakitan, Pemograman Mobile, Teknik Simulasi dan Proyek, Basis Data, Struktur Data Web Programming, Administrasi Jaringan, Sistem

35 Pakar, Logika Fuzzy, Kewirausahaan, Teknik Riset Operasi, Pengolahan Citra, Bahasa Rakitan,

36 Keamanan Komputer

Metode Penelitian, Logika Informatika, Sistem Informasi, Keamanan Komputer, Bahasa Rakitan

37 Struktur Data, Etika Profesi, Sistem Pakar, Data Mining, Pemodelan Simulasi, Manajemen Proyek, Perangkat Lunak Aplikasi, Logika Fuzzy, Pengolahan Citra

39 Etika Profesi, Basis Data, Bahasa Pemograman $\mathrm{C}++$, Manajemen Proyek, Pengolahan Citra, Sistem Pakar, Data Mining

40 Sistem Pakar, Pengolahan Citra, Sistem Informasi, Jaringan Komputer, Bahasa Rakitan, Kecerdasan Buatan, Keamanan Komputer

41 Manajemen Proyek, Perangkat Lunak Aplikasi, Sistem Pakar, Pengolahan Citra, Bahasa Rakitan, Keamanan Komputer

42 Web Programming, Algoritma dan Pemograman, Pengantar Ilmu Komputer, Struktur Data

Teori Bahasa dan Automata, Logika Informatika,

43 Administrasi Jaringan, Pemograman Client/Server, Data Mining, Logika Fuzzy

Etika Profesi, Teknik Simulasi dan Proyek,

44 Rekayasa Perangkat Lunak, Pemograman Mobile, Pemodelan Simulasi, Sistem Pakar, Data Mining, 45 Logika Fuzzy

46 Pemograman Mobile, Pemograman Client/Server, Pemodelan Simulasi, Bahasa Rakitan, Logika Informatika 
47 Basis Data, Sistem Informasi, Etika Profesi, Sistem Pakar, Kecerdasan Buatan, Kewirausahaan, Bahasa Rakitan, Metode Penelitian, Pengolahan Citra, Data Mining, Keamanan Komputer Rekayasa Perangkat Lunak, Struktur Data, 49 Algoritma dan Pemograman, Pemograman 50 Mobile, Administrasi Jaringan

Teknik Riset Operasi, Bahasa Rakitan, Teori Bahasa dan Automata, Sistem Pakar, Pengolahan Citra, Manajemen Proyek

Data Mining, Kewirausahaan, Pemograman Mobile

Administrasi Jaringan, Etika Profesi, Manajemen Proyek, Rekayasa Perangkat Lunak, Sistem Pakar, Data Mining

Sistem Pakar, Pengolahan Citra, Pemograman Client/Server, Keamanan Komputer, Logika Fuzzy, Web Programming, Bahasa Rakitan

Web Programming, Etika Profesi, Bahasa Rakitan, Pengantar Ilmu Komputer, Jaringan Komputer, Sistem Pakar, Data Mining

Data Mining, Keamanan Komputer

Teknik Simulasi Proyek, Web Programming, Data Mining, Jaringan Komputer, Logika Informatika

Misalkan diberikan nilai minimum support $\geq 15 \%$ dari 50 transaksi dan kemudian dilakukan pencarian nilai support pada masing-masing item dengan rumus. Nilai support sebuah item diperoleh dengan rumus berikut.

Support $(\mathrm{A})=($ Jumlah transaksi mengandung A (Total Transaksi)

Contohnya :

Support(Pengantar Ilmu Komputer $)=7 / 50=14 \%$

Langkah 1 :

Mencari C1 (Kandidat 1-itemset) seperti berikut

TABEL 2

KANDIDAT 1-ITEMSET(K1)

\begin{tabular}{lllc}
\multicolumn{3}{c}{ KANDIDAT 1-ITEMSET(K1) } \\
\hline \multirow{2}{*}{ No } & Daftar Bahan Ajar & Jumlah & Support \\
& & & \\
\hline 1 & Pengantar Ilmu Komputer & $7 / 50=0,14$ & $14 \%$ \\
2 & Algoritma dan Pemograman & $5 / 50=0,1$ & $10 \%$ \\
3 & Logika Informatika & $7 / 50=0,14$ & $14 \%$ \\
4 & Struktur Data & $15 / 50=0,3$ & $30 \%$ \\
5 & Rekayasa Perangkat Lunak & $5 / 50=0,1$ & $10 \%$ \\
6 & Basis Data & $6 / 50=0,12$ & $12 \%$ \\
7 & Jaringan Komputer & $7 / 50=0,14$ & $14 \%$ \\
8 & Kecerdasan Buatan & $17 / 50=0,34$ & $34 \%$ \\
9 & Manajemen Proyek & $8 / 50=0,16$ & $16 \%$ \\
10 & Teknik Simulasi dan Proyek & $4 / 50=0,08$ & $8 \%$ \\
11 & Metode Penelitian & $7 / 50=0,14$ & $14 \%$ \\
12 & Sistem Informasi & $9 / 50=0,18$ & $18 \%$ \\
13 & Pengolahan Citra & $19 / 50=0,38$ & $38 \%$ \\
14 & Sistem Pakar & $24 / 50=0,48$ & $48 \%$ \\
15 & Web Programming & $10 / 50=0,2$ & $20 \%$ \\
16 & Pemograman Mobile & $9 / 50=0,18$ & $18 \%$ \\
17 & Etika Profesi & $18 / 50=0,36$ & $36 \%$ \\
18 & Perangkat Lunak Aplikasi & $6 / 50=0,12$ & $12 \%$ \\
19 & Bahasa Pemograman C++ & $7 / 50=0,14$ & $14 \%$ \\
20 & Pengantar Arsitektur Komputer & $3 / 50=0,06$ & $6 \%$ \\
21 & Teknik Riset Operasi & $7 / 50=0,14$ & $14 \%$ \\
22 & Teori Bahasa dan Automata & $7 / 50=0,14$ & $14 \%$ \\
23 & Administrasi Jaringan & $11 / 50=0,22$ & $22 \%$ \\
24 & Pemograman Client/Server & $6 / 50=0,12$ & $12 \%$ \\
25 & Data Mining & $24 / 50=0,48$ & $48 \%$ \\
26 & Keamanan Komputer & $23 / 50=0,46$ & $46 \%$ \\
& &
\end{tabular}

27 Pemodelan Simulasi

28 Logika Fuzzy

29 Kewirausahaan

30 Bahasa Rakitan

$8 / 50=0,16 \quad 16 \%$

$20 / 50=0,4 \quad 40 \%$

$8 / 50=0,16 \quad 16$

$26 / 50=0,52 \quad 52 \%$

Langkah 2 :

Berdasarkan Tabel yang berisi item-item dengan support yang dimilikinya, selanjutnya cari $\mathrm{L} 1=\{$ large 1 -itemset $\}$ dengan memilih item yang memenuhi nilai minimum support $\geq 15 \%$ seperti berikut.

TABEL 3

\begin{tabular}{clll}
\hline No & Daftar Bahan Ajar & Jumlah & Support $\%$ \\
\hline & & & \\
& & & \\
1 & Administrasi Jaringan & $11 / 50=0,22$ & $22 \%$ \\
2 & Bahasa Rakitan & $26 / 50=0,52$ & $52 \%$ \\
3 & Data Mining & $24 / 50=0,48$ & $48 \%$ \\
4 & Etika Profesi & $18 / 50=0,36$ & $36 \%$ \\
5 & Kecerdasan Buatan & $17 / 50=0,34$ & $34 \%$ \\
6 & Keamanan Komputer & $23 / 50=0,46$ & $46 \%$ \\
7 & Kewirausahaan & $8 / 50=0,16$ & $16 \%$ \\
8 & Manajemen Proyek & $8 / 50=0,16$ & $16 \%$ \\
9 & Logika Fuzzy & $20 / 50=0,4$ & $40 \%$ \\
10 & Pengolahan Citra & $19 / 50=0,38$ & $38 \%$ \\
11 & Pemograman Mobile & $9 / 50=0,18$ & $18 \%$ \\
12 & Pemodelan Simulasi & $8 / 50=0,16$ & $16 \%$ \\
13 & Struktur Data & $15 / 50=0,3$ & $30 \%$ \\
14 & Sistem Informasi & $9 / 50=0,18$ & $18 \%$ \\
15 & Sistem Pakar & $24 / 50=0,48$ & $48 \%$ \\
16 & Web Programming & $10 / 50=0,2$ & $20 \%$ \\
& & & \\
\hline
\end{tabular}

Selanjutnya dimisalkan nilai minimum confidence $50 \%$, maka aturan asosiasi yang terbentuk adalah sebagai berikut:

TABEL 4

\begin{tabular}{|c|c|c|c|}
\hline No & Daftar Bahan Ajar & Jumlah & Support \% \\
\hline 1 & $\begin{array}{l}\text { Bahasa Rakitan, Keamanan } \\
\text { Komputer }\end{array}$ & $21 / 26=0,8077$ & $80,77 \%$ \\
\hline 2 & $\begin{array}{l}\text { Bahasa Rakitan, Pengolahan } \\
\text { Citra }\end{array}$ & $16 / 26=0,6154$ & $61,54 \%$ \\
\hline 3 & $\begin{array}{l}\text { Bahasa Rakitan, Sistem } \\
\text { Pakar }\end{array}$ & $14 / 26=0,5358$ & $53,58 \%$ \\
\hline 4 & Data Mining, Etika Profesi & $16 / 24=0,6667$ & $66,67 \%$ \\
\hline 5 & Data Mining, Logika Fuzzy & $16 / 24=0,6667$ & $66,67 \%$ \\
\hline 6 & Data Mining, Sistem Pakar & $15 / 24=0,625$ & $62,5 \%$ \\
\hline 7 & Etika Profesi, Data Mining & $16 / 18=0,8889$ & $88,89 \%$ \\
\hline 8 & $\begin{array}{l}\text { Etika Profesi, Kecerdasan } \\
\text { Buatan }\end{array}$ & $11 / 18=0,6111$ & $61,11 \%$ \\
\hline 9 & Etika Profesi, Logika Fuzzy & $12 / 18=0,6667$ & $66,67 \%$ \\
\hline 10 & $\begin{array}{l}\text { Etika Profesi, Pengolahan } \\
\text { Citra }\end{array}$ & $9 / 18=0,50$ & $50 \%$ \\
\hline 11 & Etika Profesi, Struktur Data & $11 / 18=0,6111$ & $61,11 \%$ \\
\hline 12 & Etika Profesi, Sistem Pakar & $16 / 18=0,8889$ & $88,89 \%$ \\
\hline 13 & $\begin{array}{l}\text { Kecerdasan Buatan, Bahasa } \\
\text { Rakitan }\end{array}$ & $10 / 17=0,5882$ & $58,82 \%$ \\
\hline 14 & $\begin{array}{l}\text { Kecerdasan Buatan, Data } \\
\text { Mining }\end{array}$ & $11 / 17=0,6471$ & $64,71 \%$ \\
\hline 15 & $\begin{array}{l}\text { Kecerdasan Buatan, Etika } \\
\text { Profesi }\end{array}$ & $11 / 17=0,6471$ & $64,71 \%$ \\
\hline 16 & $\begin{array}{l}\text { Kecerdasan Buatan, } \\
\text { Keamanan Komputer }\end{array}$ & $10 / 17=0,5882$ & $58,82 \%$ \\
\hline 17 & Kecerdasan Buatan, Logika & $10 / 17=0,5882$ & $58,82 \%$ \\
\hline
\end{tabular}


Fuzzy

18 Kecerdasan Buatan, Pengolahan Citra

19 Kecerdasan Buatan, Struktur Data

20 Kecerdasan Buatan, Sistem Pakar

21 Keamanan Komputer, Bahasa Rakitan

22 Keamanan Komputer, Pengolahan Citra

23 Keamanan Komputer, Sistem Pakar

24 Kewirausahaan, Bahasa Rakitan

25 Kewirausahaan, Data Mining

26 Kewirausahaan, Kecerdasan Buatan

27 Kewirausahaan, Keamanan Komputer

28 Logika Fuzzy, Data Mining

29 Logika Fuzzy, Etika Profesi

30 Logika Fuzzy, Kecerdasan Buatan

31 Logika Fuzzy, Keamanan Komputer

32 Logika Fuzzy, Struktur Data

33 Logika Fuzzy, Sistem Pakar

34 Manajemen Proyek, Bahasa Rakitan

35 Manajemen Proyek, Data Mining

36 Manajemen Proyek, Etika Profesi

37 Manajemen Proyek, Keamanan Komputer

38 Manajemen Proyek, Pengolahan Citra

39 Manajemen Proyek, Sistem Pakar

40 Pengolahan Citra, Bahasa Rakitan

41 Pengolahan Citra, Keamanan Komputer

42 Pengolahan Citra, Sistem Pakar

43 Pemograman Mobile, Data Mining

44 Pemograman Mobile, Etika Profesi

45 Pemodelan Simulasi, Bahasa Rakitan

46 Pemodelan Simulasi, Data Mining

47 Pemodelan Simulasi, Etika Profesi

48 Pemodelan Simulasi, Logika Fuzzy

49 Pemodelan Simulasi, Sistem Pakar

50 Struktur Data, Data Mining

51 Struktur Data, Etika Profesi

52 Struktur Data, Kecerdasan Buatan

53 Struktur Data, Logika Fuzzy

54 Struktur Data, Pengolahan Citra

55 Struktur Data, Sistem Pakar

56 Sistem Informasi, Bahasa Rakitan

57 Sistem Informasi, Kecerdasan Buatan

58 Sistem Informasi,

\begin{tabular}{|c|c|}
\hline $9 / 17=0,5294$ & $52,94 \%$ \\
\hline $10 / 17=0,5882$ & $58,82 \%$ \\
\hline $12 / 17=0,7059$ & $70,59 \%$ \\
\hline $21 / 23=0,913$ & $91,3 \%$ \\
\hline
\end{tabular}

$14 / 23=0,6087 \quad 60,87 \%$

$13 / 23=0,5652 \quad 56,52 \%$

$5 / 8=0,625 \quad 62,5 \%$

$4 / 8=0,50$

$4 / 8=0,50$

$5 / 8=0,625$

$16 / 20=0,80$

$12 / 20=0,60$

$10 / 20=0,50$

$10 / 20=0,50$

$10 / 20=0,50$

$13 / 20=0,65$

$5 / 8=0,625$

$5 / 8=0,625$

$4 / 8=0,50$

$4 / 8=0,50$

$5 / 8=0,625$

$6 / 8=0,75$

$16 / 19=0,8421$

$14 / 19=0,7368$

$16 / 19=0,8421$

$5 / 9=0,5556$

$5 / 9=0,5556$

$4 / 8=0,50$

$4 / 8=0,50$

$4 / 8=0,50$

$6 / 8=0,75$

$4 / 8=0,50$

$10 / 15=0,6667$

$11 / 15=0,7333$

$10 / 15=0,6667$

$10 / 15=0,6667$

$8 / 15=0,5333$

$10 / 15=0,6667$

$5 / 9=0,5556$

$5 / 9=0,5556$

$5 / 9=0,5556$
Keamanan Kompute

59 Sistem Pakar, Bahasa 14/24=0,5833 58,33\% Rakitan

60 Sistem Pakar, Data Mining $\quad 15 / 24=0,625 \quad 62,5 \%$

61 Sistem Pakar, Etika Profesi $\quad 16 / 24=0,6667 \quad 66,67 \%$

62 Sistem Pakar, Kecerdasan 12/24=0,50 50\% Buatan

63 Sistem Pakar, Keamanan 13/24=0,5417 54,17\% Komputer

Dari tahap-tahap yang telah dilakukan di atas, maka item yang memenuhi Support x Confidence terbesar dan minimum confidence $\geq 50 \%$ sehingga aturan asosiasi yang berurut.

TABEL 5
Aturan Asosiasi

No Aturan Asosiasi

1 Jika membeli bahan ajar Bahasa Rakitan maka akan membeli Keamanan Komputer dengan confidence $80,77 \%$

2 Jika membeli bahan ajar Manajemen Proyek maka akan membeli Data Mining dengan confidence $62,5 \%$

3 Jika membeli bahan ajar Manajemen Proyek maka akan membeli Etika Profesi dengan confidence $50 \%$

$4 \quad$ Jika membeli bahan ajar Manajemen Proyek maka akan membeli Keamanan Komputer dengan confidence $50 \%$

5 Jika membeli bahan ajar Manajemen Proyek maka akan membeli Pengolahan Citra dengan confidence $62,5 \%$

6 Jika membeli bahan ajar Manajemen Proyek maka akan membeli Sistem Pakar dengan confidence $75 \%$

7 Jika membeli bahan ajar Pengolahan Citra maka akan membeli Bahasa Rakitan dengan confidence $84,21 \%$

8 Jika membeli bahan ajar Pengolahan Citra maka akan membeli Keamanan Komputer dengan confidence $73,68 \%$

9 Jika membeli bahan ajar Pengolahan Citra maka akan membeli Sistem Pakar dengan confidence $84,21 \%$

10 Jika membeli bahan ajar Pemograman Mobile maka akan membeli Data Mining dengan confidence $55,56 \%$

11 Jika membeli bahan ajar Pemograman Mobile maka akan membeli Etika Profesi dengan confidence $55,56 \%$

12 Jika membeli bahan ajar Pemodelan Simulasi maka akan membeli Bahasa Rakitan dengan confidence $50 \%$

13 Jika membeli bahan ajar Pemodelan Simulasi maka akan membeli Data Mining dengan confidence $50 \%$

14 Jika membeli bahan ajar Pemodelan Simulasi maka akan membeli Etika Profesi dengan confidence $50 \%$

15 Jika membeli bahan ajar Pemodelan Simulasi 
maka akan membeli Logika Fuzzy dengan confidence $50 \%$

Jika membeli bahan ajar Pemodelan Simulasi maka akan membeli Sistem Pakar dengan confidence $50 \%$

Jika membeli bahan ajar Struktur Data maka akan membeli Data Mining dengan

18 confidence $66,67 \%$

Jika membeli bahan ajar Struktur Data maka akan membeli Etika Profesi dengan

19 confidence $73,33 \%$

Jika membeli bahan ajar Struktur Data maka akan membeli Kecerdasan Buatan dengan confidence $66,67 \%$

Jika membeli bahan ajar Struktur Data maka akan membeli Logika Fuzzy dengan

21 confidence $66,67 \%$

Jika membeli bahan ajar Struktur Data maka akan membeli Pengolahan Citra dengan

22 confidence $53,33 \%$

Jika membeli bahan ajar Struktur Data maka akan membeli Sistem Pakar dengan

23 confidence $66,67 \%$

Jika membeli bahan ajar Sistem Informasi maka akan membeli Bahasa Rakitan dengan confidence $55,56 \%$

Jika membeli bahan ajar Sistem Informasi maka akan membeli Kecerdasan Buatan

25 dengan confidence $55,56 \%$

Jika membeli bahan ajar Sistem Informasi maka akan membeli Keamanan Komputer dengan confidence $55,56 \%$

Jika membeli bahan ajar Sistem Pakar maka akan membeli Bahasa Rakitan dengan confidence $58,33 \%$

Jika membeli bahan ajar Sistem Pakar maka akan membeli Data Mining dengan confidence $62,5 \%$

Jika membeli bahan ajar Sistem Pakar maka akan membeli Etika Profesi dengan confidence $66,67 \%$

Jika membeli bahan ajar Sistem Pakar maka akan membeli Kecerdasan Buatan dengan

30 confidence $50 \%$

Jika membeli bahan ajar Sistem Pakar maka akan membeli Keamanan Komputer dengan confidence $54,17 \%$

31 Jika membeli bahan ajar Sistem Pakar maka

32 akan membeli Logika Fuzzy dengan confidence $54,17 \%$

Jika membeli bahan ajar Sistem Pakar maka akan membeli Pengolahan Citra dengan confidence $66,67 \%$

Jika membeli bahan ajar Web Programming maka akan membeli Bahasa Rakitan dengan confidence $50 \%$

Jika membeli bahan ajar Web Programming maka akan membeli Sistem Pakar dengan confidence $50 \%$

\subsection{Rancangan Sistem}

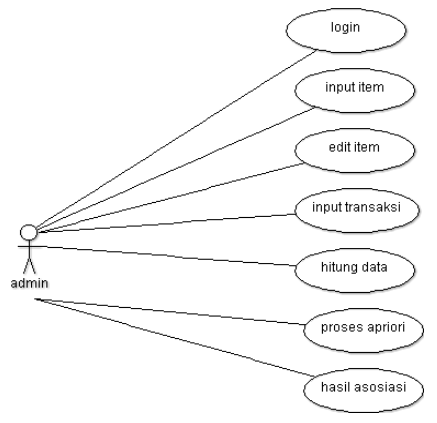

Gambar 1 Use Case Diagram

\section{Hasil Dan Pembahasan}

Secara garis besar desain halaman interface untuk proses konsultasi adalah sebagai berikut:

a. Tahapan Login

Tahapan login merupakan tahap awal user dalam menggunakan sistem.

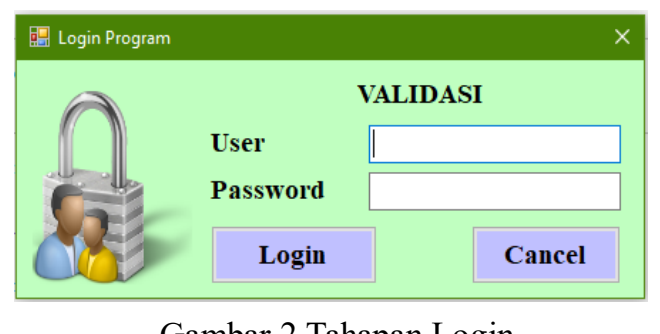

Gambar 2 Tahapan Login

b. Tahapan input item

Tahapan input item, yang berfungsi sebagai tempat pengisian, pengubahan, dan penghapusan item-item bahan ajar yang akan diproses.

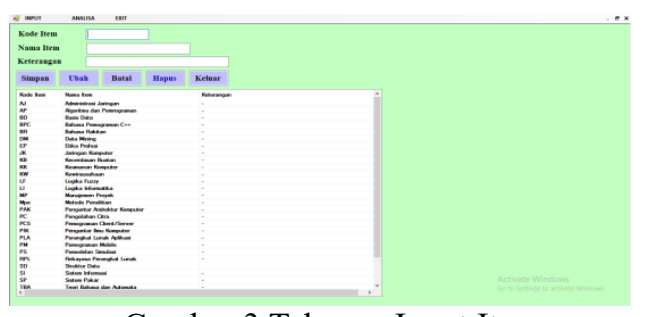

Gambar 3 Tahapan Input Item

c. Tahapan import File

Tahapan import File ini merupakan tahapan tambahan yang menampilkan nilaitabulasi dari semua data transaksi yang ada di database. 


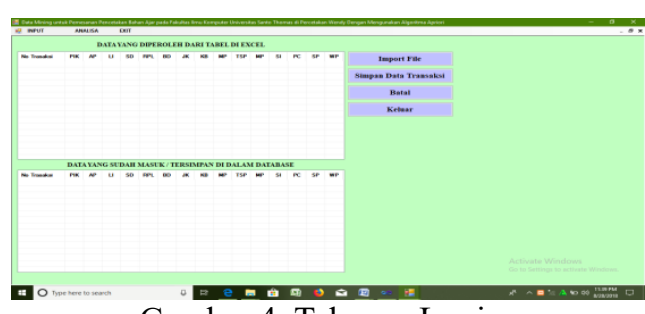

Gambar 4 Tahapan Login

d. Tahapan Transaksi

Tahapan Transaksi ini merupakan tahapan untuk jumlah transaksi yang akan diproses, form ini bisa juga berfungsi sebagai pengubahan, penambahan dan penghapusan item-item bahan ajar yang akan diproses.

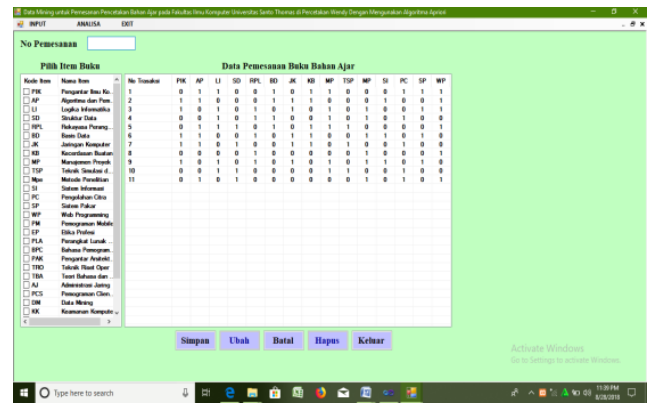

Gambar 5 Tahapan Transaksi

e. Tahapan Analisa Data Mining

Tahapan Analisa Data Mining ini merupakan form dilakukannya proses analisa dan pembentukan rule, di form ini juga pemberian nilai minimum support dan nilai minimum Confidence.

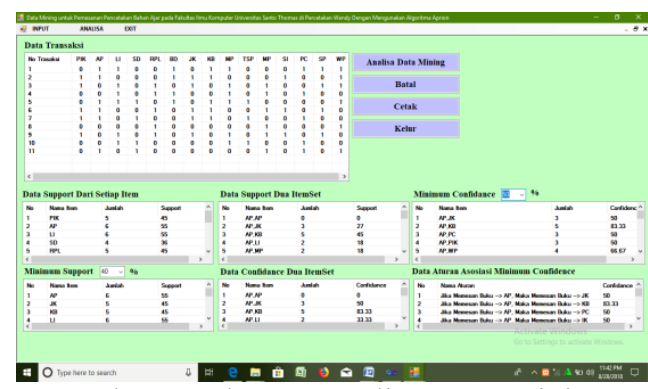

Gambar 6 Tahapan Analisa Data Mining

f. Tahap Terakhir

Tahapan akhir merupakan opsi yang diberikan oleh sistem untuk mencetak hasil transaksi, setelah proses transaksi selesai.

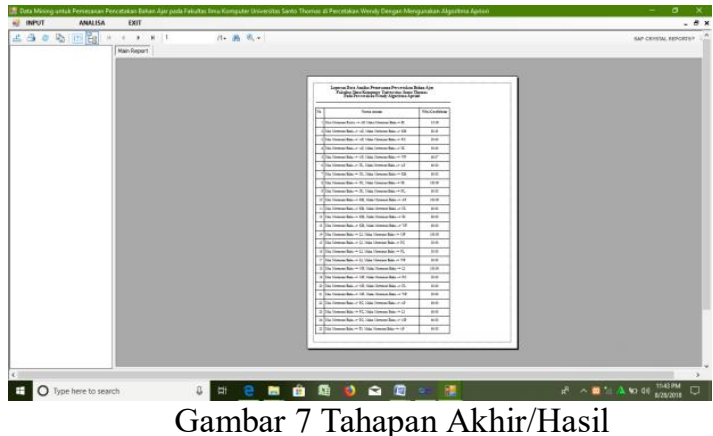

1. Pembahasan

Setelah melalui tahapan-tahapan yang telah dijelaskan sebelumnya, mulai dari login hingga diperolehnya hasil transaksi, maka dapat disimpulkan bahwa sistem yang telah dibangun telah sesuai dengan yang diharapkan, yaitu:

a. Konsumen (mahasiswa/i) tidak perlu lagi membuang-buang waktu untuk mencari atau memfotokopi buku bahan ajar yang diperlukan. Konsumen (mahasiswa/i) hanya tinggal datang ke toko yang direkomendasikan yaitu toko percetakan wendy untuk memesan buku yang diperlukan.

b. Konsumen (mahasiswa/i) tidak lagi mengeluarkan biaya yang lebih mahal, karena sudah ada harga yang ditetapkan antara pihak Fakultas Ilmu komputer dengan pihak toko percetakan, sehingga harga relatif lebih terjangkau untuk kalangan mahasiswa.

\section{Kesimpulan}

Setelah dilakukan pengujian terhadap sistem yang telah dibangun yaitu Penerapan Data Mining untuk Pemesanan Pencetakan Bahan Ajar pada Fakultas Ilmu Komputer Universitas Santo Thomas di Percetakan Wendy Dengan Mengunakan Algoritma Apriori, maka dapat diperoleh kesimpulan sebagai berikut:

1. Algoritma Apriori merupakan jenis algoritma asosiasi pada data mining yang melakukan pengambilan data untuk menentukan atruran asosiasi melalui Frenquent itemset dari suatu kombinasi item.

2. Dengan adanya sistem penelitian ini, proses pengolahan dan pencarian data menjadi lebih efisien, serta pengetahuan (Knowledge) yang didapat dalam bentuk aturan asosiasi dapat dimanfaatkan untuk penentuan layout berikutnya. 3. Dapat mengetahui bahan ajar yang sering dibeli oleh konsumen secara bersamaan.

4. Dapat digunakan sebagai alat bantu untuk meminimalisasi kesalahan pihak percetakan wendy dalam mengetahui keterkaitan antar bahan ajar yang dibeli oleh konsumen dan meningkatkan pelayanan konsumen. 


\section{Referensi}

[1] Eko Prasetyo, "Data Mining Konsep dan Aplikasi menggunakan", Andi Yogyakarta, Yogyakarta, 2012.

[2] Rosa.M.Shalahuddin, "Rekayasa Perangkat Lunak Terstruktur dan Berorientasi Objek" 2018.

[3] Kennedi Tampubolon, Hoga Saragih, Bobby Reza, "Implementasi Data Mining Algoritma Apriori Pada Sistem Persediaan Alat-Alat Kesehatan", Informasi Dan Teknologi Ilmiah (INTI), ISSN : 2339-210X.

[4] Tri Setyo Nugroho, "Implementasi Data Mining Menggunakan Algoritma Apriori untuk menentukan aturan Asosiasi pada
Penjualan Suku Cadang Sepeda Motor di Ahass Rahmat Motor Blora".

[5] Muchlisin Riadi, "Sumber Kajian Pustaka.com", 2017.

[6] Sri Dharwiyanti, Romi Satria Wahono, "Pengantar Unified Modeling Language (UML),2003, dari : osnigj.staff.gunadarma.ac.id.

[7] Nadia, Imelda, Agnes, Kurniati, Tifani, Intan,Dota, "14 Contoh Aplikasi Data Mining di Berbagai Bidang" (04 October 2017) dari : http://bigdata-madesimple.com/14-usefulapplications-of-data-mining.

[8] Rolly Yesputra. 2017. "Belajar Visual Basic. Net Dengan Visual Studio 2010”. Kisaran: Royal Asahan Press 